\title{
THE RECENT AMENDMENTS TO UCC ARTICLE 9: PROBLEMS AND SOLUTIONS
}

\author{
David Frisch *
}

\section{INTRODUCTION}

First, the old news. In 1998, the American Law Institute ("ALI") and the Uniform Law Commission ("ULC") - as sponsors of the Uniform Commercial Code ("UCC" or "Code")-gave their approval to the final text of the newest version of Article 9 ("Revised Article 9") after eight years of studying, drafting, and the inevitable wrangling between consumer and credit representatives. ${ }^{1}$ In an effort to reduce the likelihood of national nonuniformity during the transition stage as each state moved from the old version to the new at its own legislative pace, the drafters included a provision making July 1, 2001 the effective date of Revised Article 9. ${ }^{2}$ The drafters hoped that on this date Revised Article 9 would become effective nationwide. That hope was, as a practical matter, realized as all but four states adopted the date. ${ }^{3}$

* Professor of Law, University of Richmond School of Law. LL.M., Yale Law School; J.D., University of Miami School of Law; B.S., University of Pennsylvania. I would like to thank Blake Y. Boyette and the staff of the University of Richmond Law Review for their research and input.

1. See C. Scott Pryor, How Revised Article 9 Will Turn the Trustee's Strong-Arm into a Weak Finger: A Potpourri of Cases, 9 AM. BANKR. INST. L. REV. 229, 230 (2001). The project officially began in 1990 when the ALI and ULC appointed a committee to study Article 9 and recommend changes. See REPORT OF THE ARTICLE 9 STUDY COMMITTEE OF THE Permanent Editorial BoARd For THE UNIForm Commercial Code (Dec. 1, 1992) [hereinafter ARTICLE 9 REPORT]; Jean Braucher, Deadlock: Consumer Transactions Under Revised Article 9, 73 AM. BANKR. L.J. 83, 83 (1999). The committee issued its final report in 1992. Id. From the inception of the drafting process in 1993, consumer advocates and consumer credit representatives were at loggerheads. The compromise reached was that Revised Article 9 would leave untouched the old law for consumer transactions, except for some very minor changes. Thus, both sides grudgingly agreed not to oppose the statute when presented to the state legislatures for adoption. See id.

2. U.C.C. $\$ 9-701$ (2009); see id. § 9-701 cmt. ("If former Article 9 is in effect in some jurisdictions, and this Article is in effect in others, horrendous complications may arise.").

3. Prefatory Note to AMENDMEN'TS TO UNIForm COMMERCIAL CODE ARTICLE 9, at 1 (Draft for Approval 2010) [hereinafter DRAFT FOR APPROVAL], http://www.iaca.org/down 
When the study committee began its task in 1990, no one could foresee the extent to which the existing law would be rewritten. ${ }^{4}$ As it turned out, the drafting committee was not content merely cleaning up the relatively few problematic sections of old Article 9 and giving statutory recognition to electronic transactions. Instead, the drafters rewrote the entire article. Article 9 was reorganized, sixty-six new sections were added, related sections of the Code outside of Article 9 were rewritten, and numerous substantive changes were made. ${ }^{5}$ The result was a statute that dwarfed its former self in both complexity and difficulty. Those acquainted with old Article 9, in many instances, found themselves in an unfamiliar environment. The good news was, however, that by clearing up conflicting interpretations, curing judicial misconstructions, and incorporating desirable improvements that take into account technological developments and changes in business practices, the drafters did their best to provide a viable product for the new millennium.

Now to the new news. With the millennium merely a decade old, Article 9 is once again the subject of proposed amendments. In 2008, the Article 9 Review Committee ("Review Committee") was appointed by the ALI and ULC to review the practical application of Article 9 and decide whether its text and comments would benefit from revision. ${ }^{6}$ The Review Committee identified a number of specific problems that needed fixing and recommended the appointment of a committee to draft revisions to the statute ("Drafting Committee"). ${ }^{7}$ As a result, in the fall of 2008, the ALI

loads/2010Conference/STS/UCC9_AMdraft_Jul10.pdf. The Virginia General Assembly enacted the new (and improved) Article 9 during its 2000 legislative session. Act of Apr. 9 , 2000 , ch. 1007,2000 Va. Acts 2296 (codified as amended at VA. CoDE ANN. $\$ \S 8.9 \mathrm{~A}-101$ to .709 (Repl. Vol. 2001 \& Cum. Supp. 2010)). As of July 1, 2001, Revised Article 9 went into effect in all fifty states and the District of Columbia, except for Connecticut, where it went into effect October 1, 2001, ConN. GEN. STAT. §§ 42a-9-101 to -709 (2009 \& Cum. Supp. 2010), and Alabama, Florida, and Mississippi, where it went into effect January 1, 2002. Ala. Code $\S \S 7-9 A-101$ to -709 (Repl. Vol. 2006 \& Cum. Supp. 2009); Fla. STAT. ANN. §§ 679.9-101 to -709 (2003 \& Cum. Supp. 2010); MISS. CODE ANN. §§ 75-9-101 to -627 (2004 \& Cum. Supp. 2009).

4. Ironically, the study committee saw no need for a substantial overhaul of Article 9 . See ARTICLE 9 REPORT, supra note 1, at 2 ("[T] here seems to be little support or need for fundamental changes to the scope and structure of Article $9 \ldots . .7)$.

5. David Frisch, Revised Article 9: A Primer for the General Practitioner, 35 U. RICH. L. REV. 813, 815 (2001).

6. Prefatory note to DRAFT FOR APPROVAL, supra note 3, at 1.

7. See ARTICle 9 Review Comm., StatuTORY ModifiCation Issues List 1 (June 24, 2008), http://www.nccusl.org/Shared/Docs/ucc9/ucc9_IssuesList_June08.pdf. 
and ULC gave the Review Committee the go ahead to begin drafting. ${ }^{8}$ This was not to be a substantial overhaul of Article 9 on the grand scale of the Revised Article 9 project. Rather, the Review Committee decided at the outset that its work should conform to the following principles:

We should not recommend changes that would alter policy decisions made during the 1998 revision unless the current provisions appear to be creating significant problems in practice.

Recommendations for statutory change should focus on issues as to which ambiguities have been discovered in existing statutory language, where there are substantial problems in practice under the current provisions, or as to which there have been significant nonuniform amendments that suggest the need to consider revisions.

We should recommend that an issue be handled by a revision to the Official Comments rather than to the statutory text whenever we believe that the statutory language is sufficiently clear and produces the desired result, but that judicial decisions or experience in practice indicates that some clarification might be desirable. ${ }^{9}$

With that background, the Review Committee began drafting. In July 2009, the ULC gave its first reading to a draft of proposed amendments..$^{10}$ In May 2010, the ALI for the first time formally considered and approved the amendments, "subject to the discussion at the meeting and to editorial prerogative." 11 Next, the second and "final" reading by the ULC was in July $2010 .{ }^{12}$ It is anticipated that the state legislative review and enactment process will begin in $2011 . .^{13}$

8. See Prefatory Note to DRAFT FOR APPROVAL, supra note 3, at 1.

9. Id.

10. See UNIF. LAW COMM'N, ANNUAL REPORT 2008-2009, at 12 (detailing the actions taken by the Review Committee).

11. Current Projects of UCC Article 9 Review CommitTee, am. Law Inst., http://www.ali.org/index.cfm?fuseaction=projects.proj_ip\&projectid=21 (last visited Mar. 2, 2011) (explaining the approval of amendments to Article 9); see also General Meeting Information, AM. LAW INST., http://2010am.ali.org (last visited Mar. 2, 2011) (providing dates of 2010 annual meeting as of May 17-19, 2010).

12. At the closing of its annual conference on July 16,2010, ULC formally approved the amendments, subject to revision by the Committee on Style of the National Conference of Commissioners on Uniform State Laws. The amendments are available at $\mathrm{http}: / / \mathrm{www}$. law.upenn.edu/bll/archives/ulc/ucc9/2010am_approved.pdf.

13. See Barkley Clark \& Barbara Clark, UCC Revision Committee Wrestles with Individual Debtor Name Problem, EAGLE 9 NEWSL. Summer 2010, at 16, available at http:/l www.eagle9.com/newsletters/newsletter_6_1.pdf (predicting state review of Amendments will begin in "late 2010 and early 2011 "). 
This article examines three of the forthcoming amendments to Article 9 in some detail: (1) the required name of an individual on a financing statement; (2) the perfection of collateral following the debtor's relocation to a new jurisdiction; and (3) collateral acquired by a new debtor. In the interest of brevity, the discussion of other, less noteworthy, amendments of the statutory text and Official Comments is not as complete. The primary purpose of this article is to offer guidance to legal professionals confronting particular issues under current and future Article 9.

\section{THE NAME OF AN INDIVIDUAL DEBTOR ON A FINANCING STATEMENT}

\section{A. The Problem}

The creation of a security interest under Article 9 is embodied in the concept of "attachment." ${ }^{14}$ Only when it attaches does a security interest become enforceable against the debtor. ${ }^{15}$ In a nutshell, this means the secured party acquires the right-after taking the necessary steps under Part 6 of Article 9-to foreclose upon the collateral in the event of the debtor's default. But as a practical matter, the advantages gained from attachment alone may not be sufficient to permit assertion of the security interest. The secured party must still be concerned about the very real possibility that conflicting claims to the collateral might leave its interest subject to subordination or termination. ${ }^{16}$ Competing claimants include buyers to whom the debtor sold the collateral, other secured parties with a security interest in the same collateral, or, as is very often the case, the debtor's trustee in bankruptcy. ${ }^{17}$

The assertion of competing claims raises the priority issue of how the security interest is to be ranked vis-à-vis these other claims. Section 9-201 states the general rule that "[e]xcept as oth-

14. See U.C.C. $\S 9-203(b)$ (2009), which sets forth three conditions to enforceability, and thus to attachment. These three conditions are (1) a security agreement; (2) value given by the secured party; and (3) the debtor having rights, or the power to transfer rights, in the collateral. Id. In addition, Article 9 contains a statute of frauds provision that must be satisfied. Id. $\$ 9-203(\mathrm{~b})(3)(\mathrm{A})$.

15. Id. $\S 9-203(\mathrm{a})$.

16. See id. $\S 9.322$ (outlining rules of priority in competing security interests).

17. See, e.g., id. $\S 9-317$ (giving examples of competing interests that take priority over security interests). 
erwise provided in [the UCC], a security agreement is effective according to its terms between the parties, against purchasers of the collateral, and against creditors." 18 One should not assume that this apparently broad statement of priority in favor of secured parties is adequate to protect her interests. Unfortunately for secured parties, the vast number of provisions otherwise in Article 9 and elsewhere relegate this general priority rule to minor importance. These provisions take the form of specific priority rules that make the secured party's priority dependent upon "perfection" of the security interest. ${ }^{19}$ For example, under section 9317 an attached but unperfected security interest is subordinate to the rights of a lien creditor. ${ }^{20}$ Moreover, under Bankruptcy Code $\S 544(\mathrm{a})$ the debtor's trustee in bankruptcy is given the rights and powers of a hypothetical creditor who obtains a judicial lien at the date of bankruptcy, and the trustee may avoid any transfer of property of the debtor that is avoidable by such a judicial lien creditor. ${ }^{21}$ The upshot of UCC section 9-317 and Bankruptcy Code $\S 544(a)$ is to make unperfected security interests unenforceable in bankruptcy. ${ }^{22}$ Since most of the litigation concerning security interests occurs in the bankruptcy contextwhere the trustee challenges the validity of the secured party's interest-the stakes could not be higher. ${ }^{23}$ If the trustee prevails, the secured party is relegated to the status of an unsecured creditor and is paid in all too few bankruptcy dollars. ${ }^{24}$ On the other

18. Id. §9-201.

19. See, e.g., id. $\S 9-317$ (enumerating specific conflicting interests that will have priority over an unperfected security interest); id. § 9-322(a)(1)-(2) (stating the general rule that a perfected security interest will have priority over a security interest that is unperfected or subsequently perfected).

20. Id. $\S 9-317$ (a)(2). "A lien creditor" is a creditor with a judicial lien. Id. $\S 9$. 102(a)(52). Revised Article 9 for the first time creates an exception to this simple race priority rule. An unperfected security interest will have priority if, before the claimant acquires its judicial lien, the secured party satisfies one of the conditions of section 9203(b)(3) and also files a financing statement covering the collateral. See id. §9. $317(\mathrm{a})(2)(\mathrm{B})$.

21. See 11 U.S.C. § 544(a)(1) (2006).

22. See, e.g., Boberschmidt v. Soc'y Nat'l Bank (In re Jones), 226 F.3d 917, 921 (7th Cir. 2000) ("A security interest that has not been perfected prior to the filing of a bankruptcy is unenforceable against the trustee." (citing In re Vitreous Steel Products Co., 911 F.2d 1223, 1235 (7th Cir. 1990))).

23. See, e.g., id. at 919, 921 (holding in favor of the trustee who had challenged the validity of the $\$ 221,295.50$ payment made to the bank from the proceeds of the debtor's foreclosed home sale because the bank's interest was not perfected prior to the debtor's bankruptcy filing).

24. See, e.g., In re Wheaton Oaks Office Partners Ltd., 27 F.3d 1234, 1244 (7th Cir. 1994) (stating that if a secured party has not perfected his interest, "then the trustee in 
hand, a win for the secured party means that it receives the value of the collateral or the amount of its claim, whichever is less. ${ }^{25}$ So even ignoring the many other priority rules that subordinate or eliminate attached but unperfected security interests, ${ }^{26}$ no reasonable secured party would, under any circumstances, intentionally allow its security interest to remain unperfected.

Perfection occurs when a security interest has attached and when the applicable perfection steps have been taken. ${ }^{27}$ These steps are specified in UCC sections 9-310 through 9-316. ${ }^{28}$ For security interests in goods, the preferred method of perfection is filing a financing statement. ${ }^{29}$ For security interests in certain intangible property (e.g., accounts and general intangibles) filing is the exclusive method of perfection..$^{30}$ It is fair to say, therefore, that financing statements and the state filing systems in which they are filed are of paramount importance to the efficient operation of Article 9.

The purpose of filing, and perfection in general, is to provide notice regarding the status of a debtor's property, so that those dealing with the debtor may protect their interest and act in a commercially prudent manner. The existence of a security interest should be determinable under the Code before another lender commits itself to providing additional funding to the debtor or a prospective buyer makes a final decision to purchase the collater-

bankruptcy ... can subordinate or 'avoid' that interest, thus relegating it to a status of a general creditor of the bankruptcy estate").

25. For these reasons, it has been noted that " $[t]$ he acid test for a security interest, lien, or mortgage is whether it can withstand challenge and avoidance in bankruptcy proceedings." John C. Minahan, Jr., Rents and Profits in Bankruptcy: A Nebraska Primer and Consideration of L.B. 14, 27 CREIGHTON L. REV. 158, 168 (1993).

26. See, e.g., U.C.C. \$ 9-317(b), (d) (2009) (establishing that an unperfected secured interest is lost when collateral is purchased by non-ordinary course, good faith buyers who complete the process of buying "without knowledge of the security interest"); id. $\S 9$ 322(a)(2) ("A perfected security interest . . . has priority over a conflicting unperfected security interest ....").

27. Id. § 9-308(a).

28. Id.

29. See id. $\S 9-310(a)$. Perfection by taking possession of the goods is also an option, but, in most cases, a far less practical one. See id. $\$$ 9-310(b)(6), 9-313.

30. Section 9-310(a) declares that "a financing statement must be filed to perfect all security interests," unless an exception to the default step of filing is applicable. Id. § 9310 (a). For some types of collateral, such as accounts and general intangibles, there is no exception. It should be noted that there are a few types of collateral for which the exception to filing provides not an additional perfection method, but the exclusive perfection method. See, e.g., id. $\S 9.312(\mathrm{~b})(1)$ ("[A] security interest in a deposit account may be perfected only by control. ..."). 
al. ${ }^{31}$ Notwithstanding the importance of publicizing its security interest to third parties, the financing statement that the secured party is required to file will contain very little information regarding the secured transaction. Thus, Article 9 codifies the concept of "notice filing." ${ }^{32}$ To be sufficient, a financing statement that does not relate real estate-related collateral must include (1) the name of the debtor; (2) the name of the secured party; and (3) an indication of the collateral covered ${ }^{33}$ Because financing statements are indexed under the debtor's name, using the correct name is the key to the filing system. ${ }^{34}$ Therefore, it should come as no surprise that there is an ever-growing number of reported cases involving this simple-sounding requirement. ${ }^{35}$ One issue in the existing case law can be illustrated by the following not-sohypothetical fact pattern: The debtor's legal name is "Terrance Joseph Kinderknecht." The financing statement provided the debtor's name as "Terry J. Kinderknecht." The debtor frequently refers to himself as "Terry J. Kinderknecht" and, in fact, used that name when he signed his bankruptcy petition. Is the financing statement sufficient to perfect the secured party's interest? ${ }^{36}$

First, we turn to section 9-503, which purports to provide guidance on what constitutes the debtor's name for filing and searching purposes. ${ }^{37}$ For example, if the debtor is a "registered organization" ${ }^{38}$ the name is sufficient "only if the financing statement

31. In a few circumstances perfection occurs automatically upon attachment. Id. §§ 9$310(\mathrm{~b})(2), 9-309$. Obviously, when this is the case, third parties must rely exclusively on the debtor to provide truthful information regarding the status of the collateral. These exceptions to the notice policy of perfection are supported by competing policies.

32. This concept is thoroughly explained in Official Comment 2 to section 9-502, stating, "The notice itself indicates merely that a person may have a security interest in the collateral indicated. Further inquiry from the parties concerned will be necessary to dis. close the complete state of affairs." Id. $\$ 9-502 \mathrm{cmt} .2$.

33. Id. $\S 9-502(\mathrm{a})$. Notwithstanding the minimal information requirements of section 9-502, the filing officer is prohibited by section 9-520(a) from accepting a filing that does not contain the additional information required under section 9-516(b). Id. \$ 9-520(a).

34. See id. $\S 9-519(c)(1),(f)(1)$.

35. See, e.g., Clark v. Deere \& Co. (In re Kinderknecht), 308 B.R. 71, 73 (B.A.P. 10th Cir. 2004); Miller v. Van Dorn Demag Corp. (In re Asheboro Precision Plastics, Inc.), No. 03-11319C-7G, 2005 WL 1287743, at *8 (Bankr. M.D.N.C. Mar. 1, 2005); In re FV Steel \& Wire Co., 310 B.R. 390, 394 (Bankr. E.D. Wis. 2004).

36. This was the very issue facing the Bankruptcy Appellate Panel for the Tenth Circuit in In re Kinderknecht, 308 B.R. at 72. After considering both the text of Article 9 and several policies that underlie the name requirement, the panel held that the secured party was unperfected. Id. at 72-73.

37. U.C.C. $\S 9-503$.

38. A registered organization is "an organization organized solely under the law of a 
provides the name of the debtor indicated on the public record of the debtor's jurisdiction of organization which shows the debtor to have been organized." ${ }^{39}$ But what qualifies as a sufficient name if the debtor is an individual? The seemingly straightforward statutory mandate that the financing statement should set forth the individual name of the debtor is hardly sufficient to resolve many of the issues that are likely to arise. ${ }^{40}$ In the case of Mr. Kinderknecht, the secured party will argue that because the statute does not require the debtor's "legal name," the correct name can be a nickname or other commonly used name. Put more broadly, there can be several correct names, and to qualify, a name need only be one under which a reasonably diligent searcher might choose to search. ${ }^{41}$ In response, it can be argued that since section 9-503 rejects a diligent searcher approach with respect to the name of registered organizations, the general policy of Revised Article 9 is that searching parties need only perform a single search to locate filed financing statements for any particular debtor. ${ }^{42}$ Indeed, this is certainly the prevailing view among those experts who actively participated in the drafting of the revised text. For example, one member of the drafting committee wrote that:

[Article 9] does not burden searchers with the obligation to dream up every potential error and name variation and perform searches under all possibilities. Revised Article 9 allows a searcher to rely on a single search conducted under the correct name of the debtor and penalizes filers only for errors that result in nondisclosure of the financing statement in a search under the correct name. ${ }^{43}$

single State or the United States and as to which the State or the United States must maintain a public record showing the organization to have been organized." Id. § 9102(a)(70). Common examples of a registered organization "include corporations, limited partnerships, and limited liability companies." Id. § 9-503 cmt. 2.

39. Id. § 9.503(a)(1):

40. Id. §9-503(a)(4)(A).

41. This view is not without case law support. See, e.g., Nazar v. Bucklin Nat'l Bank (In re Erwin), 2003 WL 21513158, at *24 (Bankr. D. Kan. June 27, 2003) (holding that because section 9-503 does not require an individual's full legal name, the use of the debtor's nickname "Mike Erwin" was sufficient to identify "Michael A. Erwin").

42. U.C.C. $\$ 9-503 \mathrm{cmt} .2$.

43. Harry C. Sigman, The Filing System Under Revised Article 9,73 AM. BANKR. L.J. 61, 73 (1999) (footnote omitted); see also Darrell W. Pierce, Revised Article 9 of the Uniform Commercial Code: Filing System Improvements and Their Rationale, 31 UCC L.J. 16, 17 (1998) ("Case law that has served to protect filers at the expense of searchers by giving effect to filings not readily retrievable by a search will be overturned by Revised Article 9 . ... and, in so doing, obviates the need for complicated search logic and multiple name searches."). 
The Kinderknecht court, in denying the effectiveness of the filing, ${ }^{44}$ correctly understood the principal benefits of an exacting standard with respect to debtors' names. When the need to conduct multiple searches using variations of the debtor's name is eliminated, this provides more certainty in the commercial world and reduces litigation. ${ }^{45}$ Moreover, placing the responsibility to investigate and use the exact name of a debtor upon secured parties does not seem unduly burdensome in light of the fact that a reasonably prudent creditor has access to that information. ${ }^{46}$

Assuming that all courts can be persuaded that a legal name requirement for individuals makes perfect sense and accurately reflects the drafters' appreciation of the utility that such an approach would provide, would this settle all the questions surrounding the correct name for individuals? ${ }^{47}$ The simple answer is that it would not. Uncertainty would continue to plague secured parties in their quest for the debtor's so-called legal name in many situations where the debtor legally uses or has used more than one name. ${ }^{48}$ For example, which name would the secured party use if the debtor's name on her birth certificate does not match the name on her social security card, which in turn does not match the name on her driver's license? To further complicate matters, suppose the debtor continues to use her name for business purposes, but adopts her husband's surname when the pur-

44. Clark v. Deere \& Co. (In re Kinderknecht), 308 B.R. 71, 76-77 (B.A.P. 10th Cir. 2004).

45. See id. at 75-76; see also In re FV Steel \& Wire Co., 310 B.R. 390, 394 (Bankr. E.D. Wis. 2004) (holding that "[a] rule that would burden a searcher with guessing at misspellings and various configurations of a legal name would" decrease the certainty desirable in commercial transactions and that the burden of filing under the correct name is properly on the filer (quoting First Nat'l Bank of Lacon v. Strong, 663 N.E.2d 432, 435 (Ill. App. Ct. 1996))). Even in those cases where the secured party files under an incorrect name, all is not necessarily lost. Section 9-506(c) provides a safe harbor rule that would save a filing with an erroneous debtor name "[i]f a search of the records of the filing office under the debtor's correct name, using the filing office's standard search logic, if any, would disclose" the filing. U.C.C. \$ 9-506(c).

46. See In re Kinderknecht, 308 B.R. at 76.

47. It should be noted that however the problem of individual names is resolved, that same solution would presumably apply when the financing statement is required to give the name of an individual trustee or settlor of a trust, see U.C.C. § 9-503(a)(3), or a decedent, see id. $\S 9-503(\mathrm{a})(2)$, or an individual member of an organization without a name, see id. $\S 9-503(\mathrm{a})(4)(\mathrm{B})$.

48. Cf. Fid. \& Deposit Co. of Md. v. Bodenstedt, 104 N.W.2d 292, 296 (Neb. 1960) (citation omitted) (explaining that a person can use any name to "transact business, execute contracts, and carry on his affairs, unless he does so in order to defraud others"). 
pose is personal. What name then? ${ }^{49} \mathrm{It}$ is to the Drafting Committee's solution that we now turn.

\section{B. The Solution}

Balancing competing policy concerns, the Review Committee opted in favor of producing two alternative approaches to the problem of individual debtor names from which states may choose. The first alternative requires filings against the name of the debtor as stated on the most recent unexpired driver's license. ${ }^{50}$ This approach clearly reduces the risks and burdens of determining the debtor's correct name on the secured party who files and the third party who searches. If the debtor does not have a current license, then the test for sufficiency will remain what it was before (unclear) but with what misleadingly appears to be a safe harbor. A filing will be sufficient if it uses the debtor's surname and first personal name. ${ }^{51}$ But what is the debtor's first personal name? Would "Terry" qualify as Mr. Kinderknecht's first name? And what is the debtor's correct surname? Could it be the debtor's maiden name if used for business purposes only? It was hoped that the Official Comments would offer guidance on these issues, but alas, there is only silence. ${ }^{52}$

The second alternative does little to reduce the current uncertainty facing searchers, but does provide comfort to those who file. A filing will be sufficient if it uses the name as it appears on the debtor's current driver's license, but there is no requirement

49. Several states, including Virginia, have responded to this problem by enacting non-uniform amendments to their versions of Article 9. See, e.g., TENN. CODE ANN. $\S 47-9$ 503(a)(4), (f) (Supp. 2010); TEX. BUS. \& CoM. CODE ANN. § 9.503(a)(4) (West Supp. 2009); VA. CODE ANN. $\S 8.9 A-503(a)(4)$ (Cum. Supp. 2010). The Article 9 Review Committee recognized that other filing issues included "those relating to foreign individual names, names in foreign alphabets and accented, hyphenated or like names that may challenge a filing office's indexing or search logic." ARTICLE 9 REVIEW COMM., supra note 7, at 3 n.3.

50. U.C.C. $\$ 9-503(a)(4)$ (Alt. A) (Approved Amendments 2010). Because the law that governs perfection is the law of the state in which the debtor maintains her principal residence, see id. $\S 9-301(1)$ (2009), the license that matters is the one issued by this state. The amended Official Comments to section 9-503 make the point that the name used in the financing statement must be exactly the same as the name on the driver's license. Id. $\S 9$ $503 \mathrm{cmt}$. 2d (Approved Amendments 2010). Thus, if the name on the license is "Joseph Allan Jones," a filing against "Joseph Jones" or "Joseph A. Jones" would not be sufficient. See id.

51. Id. \$ 9-503(a)(5) (Alt. A).

52. See id. $\S 9-503 \mathrm{cmt}$. $2 \mathrm{~d}$ ("In disputes as to whether a financing statement sufficiently provides the 'individual name' of a debtor, a court should refer to any non-UCC law concerning names."). 
that the secured party use this name. ${ }^{53}$ It is merely a safe harbor for secured parties. The debtor's individual name would also suffice, as would the debtor's surname and first personal name. ${ }^{54}$ Thus, in those states adopting this alternative, searchers must search under the name on the driver's license and would be wise to search under other names that the debtor is known to use.

\section{Collateral ACQUiRed By A DeBToR Following RELOCATION}

\section{A. The Problem}

Under the rules of Revised Article 9, all financing statements are filed in the jurisdiction of the debtor's location. ${ }^{55}$ But in order to determine where the debtor is located, one must consult section 9-307. If the debtor is incorporated or otherwise organized as a registered organization, its location is the state in which it is registered.$^{56}$ If the debtor is an unregistered entity, it is located in the state in which it maintains its chief executive office. ${ }^{57}$ The location of an individual is his or her principal residence.$^{58}$

So far, so good. But what happens if the debtor subsequently changes its location to another jurisdiction? Consider the following example:

Example 1: Debtor is an individual who resides in Virginia and is the sole proprietor of a hardware store. Debtor grants to Lender a security interest in specific items of equipment. Lender properly perfects by filing its financing statement in Virginia. Debtor then relocates to North Carolina.

The relocation of Debtor's principal residence to North Carolina constitutes a change in Debtor's location and, therefore, a change in the law of the jurisdiction governing perfection. Section 9316 (a) provides that the security interest remains perfected for four months after the change ${ }^{59}$ and is continuously perfected under section 9-316(b) if it is perfected in the new location within

53. See id. § 9-503(a)(4) (Alt. B).

54. See id.

55. See id. § 9.301(1) (2009).

56. See id. § 9-307(e).

57. See id. § 9-307(b)(3).

58. See id. § 9-307(b)(1).

59. See id. § 9-316(a)(2). 
the four-month period. ${ }^{60}$ If it is not perfected within that period, "the security interest... becomes unperfected and is deemed never to have been perfected as against a purchaser of the collateral for value." ${ }^{61}$ Thus, in the foregoing example, Lender is given four months to discover that Debtor has moved and perfect in North Carolina if it wishes to maintain its security interest without a lapse in perfection. ${ }^{62}$ The failure to reperfect within the statutory grace period does not just mean that Lender's security interest becomes vulnerable to competing interests that come into existence after that period expires (when the security interest is no longer perfected), it also means that Lender's priority over interests that attached before or within the four-month period might be lost. ${ }^{63}$

The consequence of all this for the secured party is that it must periodically monitor the location of the debtor. A third party who is interested in the debtor's title to the collateral needs to ascertain whether the debtor has changed its location within the previous four months. If it has, the third party must search for filings in the state where the debtor is currently located and in its former state of location. This seems to be a fair compromise.

Example 2: Under the facts of Example 1, Debtor has also granted to Lender a security interest in Debtor's existing and after-acquired inventory. After Debtor moves to North Carolina, he continues to acquire new inventory to which Lender's security interest attaches.

Because Debtor is now located in North Carolina, Lender will need to take the necessary steps for perfection in that state. As

60. Id. § 9-316(b).

61. Id.

62. This four-month fixed period assumes that the filing in Virginia does not for some reason become ineffective before then. If it does, and if Lender had not yet filed in North Carolina, its perfection would be lost, even if the four-month period had not yet expired. See id. §9-316(a).

63. This is because, as against a purchaser for value, the failure to reperfect during the four-month grace period results in a retroactive loss of perfection. Id. $\$$ 9-316(b). Under section 1-201(a)(30), a "purchaser" includes any person who has acquired an interest in the collateral by virtue of a consensual transaction with the debtor. See id. $\$ 1-201(a)(30)$. This would include secured parties. Yet, what policy justifies a reversal of priorities upon Lender's failure to reperfect? The answer is far from obvious. See David Frisch, The Implicit "Takings" Jurisprudence of Article 9 of the Uniform Commercial Code, 64 FORDHAM L. REv. 11, $36 \mathrm{n} .118$ (1995) (suggesting a justification for this reversal of priorities is that it provides a "method for untangling the circular priority dispute that would arise if the Code permitted [Lender] to retain its priority"). 
indicated in the discussion following Example 1, the security interest perfected by the filing in Virginia continues to be perfected for four months following the Debtor's relocation. Note that section 9-316(a) limits this grace period to security interests that are perfected prior to Debtor's relocation to the new jurisdiction. ${ }^{64}$ Thus, the four-month rule has no application to security interests that have not attached before the location changes. The result is that Lender's security interest in the store's inventory on the relocation date will remain perfected for four months, but as to those items acquired by Debtor after relocating to North Carolina, the security interest will remain unperfected until Lender files in North Carolina.

Observe that section 9-316(a) significantly increases the burden on the secured party to monitor the debtor when the security interest extends to any type of after-acquired collateral ${ }^{65}$ Lender in Example 1 need only check on the location of Debtor every four months to ensure that its security interest remains perfected, whereas Lender in the present example is never really safe. The problem is exacerbated when, as here, the collateral is the type that turns over continually and for which it would make little commercial sense for the secured party to be content with a security interest that was perfected only in the inventory that was on hand at the time of Debtor's relocation. What accounts for imposing a greater burden on the secured party with respect to postlocation collateral than with respect to pre-location collateral? Should Amended Article 9 take a different approach? The Drafting Committee's answer was yes.

\section{B. The Solution}

Amended Article 9 reflects the drafter's appreciation that little is to be gained by a four-month rule that draws a sharp distinction between collateral acquired by the debtor prior to its relocation to another jurisdiction and collateral acquired after relocation. The current grace period enjoyed by secured parties supplies a strong incentive for third parties to check for filings in the state where the debtor was previously located, notwithstanding the fact that the filing would be ineffective to perfect a security interest in

64. See U.C.C. §9-316(a).

65. See id. 
collateral acquired after the debtor's relocation to the new state. Thus, it is unlikely that expanding the scope of the grace period to include all collateral would have much, if any, impact on the search burden imposed on third parties. But it would significantly reduce the monitoring burden on secured parties.

To achieve this more efficient balancing of burdens, the drafters of Amended Article 9 have added a new subsection (h) to section 9-316. ${ }^{66}$ No longer will it matter when the security interest attaches. The filing in the original state will be effective for all collateral for four months. ${ }^{67}$

\section{COllateral ACQUiRED By A NEW DEBTOR}

\section{A. The Problem}

In Revised Article 9 terminology, a "new debtor" is "a person that becomes bound as debtor under Section 9-203(d) by a security agreement previously entered into by another person." ${ }^{\prime 68}$ What makes new debtor status significant is that the existing security agreement would give the secured party a security interest in the new debtor's existing and after-acquired collateral of the kinds described in the security agreement. Simply put, the new debtor is treated as if it were the original debtor. ${ }^{69}$ When does this occur? Section 9-203(d) tells us that:

A person becomes bound as [a] debtor by a security agreement entered into by another person if, [either] by operation of law ... or by contract:

66. See id. § 9-316(h) (Approved Amendments 2010).

67. Id. The Reporter's Note to amended section 9-316 explains the reason for the change:

Given the risks faced by an existing secured party whose security interest in property acquired by the debtor after relocation is unperfected and the likelihood that a later purchaser would in any event investigate the pedigree of the affected property and search for filings in the original state, the [drafting committee] decided that the benefits to the existing secured party in not having to monitor the debtor more frequently than every four months for a change of location outweigh the burden placed on purchasers of the affected property.

U.C.C. § 9-316 reporter's note 2 (Tentative Draft No. 1, Apr. 11, 2010).

68. Id. §9-102(a)(56) (2009). The person who previously entered into the security agreement is called the "original debtor." Id. § 9-102(a)(60).

69. See id. § 9.203(e). 
(1) the security agreement becomes effective to create a security interest in the person's property; or

(2) the person becomes generally obligated for the obligations of the other person, including the obligation secured under the security agreement, and acquires or succeeds to all or substantially all of the assets of the other person. ${ }^{70}$

Now, consider an example drawn from the facts of Example 5 in the Official Comments to section 9-316:

Debtor is a Pennsylvania corporation. Debtor grants to Lender a security interest in Debtor's existing and after-acquired inventory. Lender perfects by filing in Pennsylvania. Debtor's shareholders decide to "reincorporate" in Delaware. They form a Delaware corporation (Newcorp) into which they merge Debtor. By virtue of the merger, Newcorp becomes bound by Debtor's security agreement. After the merger, Newcorp acquires inventory to which Lender's security interest attaches. ${ }^{71}$

It may seem, at first glance, that this fact pattern is no different from that discussed in the preceding Part. That is, we have, in effect, a relocation of Debtor from Pennsylvania to Delaware. But here there is an important difference. The difference results from the simple fact that Newcorp is a different juridical person from Debtor. Under these circumstances, the applicable rule is found, not in section 9-316(a)(2), but rather, in section 9-316(a)(3). That section provides for a one-year grace period (assuming that the Pennsylvania filing does not lapse before then) when collateral is transferred to a person "that thereby becomes a debtor" and is located in another jurisdiction. ${ }^{72}$ Thus, as to the inventory actually transferred by Debtor to Newcorp, Lender would have one year to file in Delaware.

70. Id. $\S 9-203(\mathrm{~d})$. Comment 3 to section $9-508$ provides several examples of how section 9-203(d) would operate in the merger context. One is particularly helpful.

[S]ome corporate laws provide that, when two corporations merge, the surviving corporation succeeds to the assets of its merger partner and "has all liabilities" of both corporations. In the case where, for example, A Corp merges into B Corp (and A Corp ceases to exist), some people have questioned whether A Corp's grant of a security interest in its existing and after-acquired property becomes a "liability" of B Corp, such that B Corp's existing and after-acquired property becomes . . . subject to a security interest in favor of A Corp's lender. Even if corporate law were to give a negative answer, under Section 9-203(d)(2), B Corp would become bound for purposes of Section 9203(e) and this section.

Id. $\S 9-508 \mathrm{cmt}$. 3.

71. Id. § $9-316 \mathrm{cmt} .2$ (internal citation omitted).

72. Id. §9-316(a)(3). 
As we have seen in the discussion of the four-month grace period governing relocations, current section 9-316 does not help the secured party if the security interest first attaches after the relocation. ${ }^{73}$ The same is true here, where a new debtor is located in another jurisdiction. Lender's security interest in property acquired by Newcorp would be unperfected until Lender files an otherwise effective financing statement in Delaware. The practical problem for the secured party is that the new debtor may come into existence under circumstances that go unnoticed by even the most diligent lender and not signal the need to take steps to maintain the perfected status of its security interest in afteracquired property. Such might be the case where the new debtor results from a restructuring of the debtor's business that involves little more than paperwork.

\section{B. The Solution}

Nothing in the Article 9 amendments changes the existing oneyear grace period for collateral that was transferred by the original debtor to the new debtor. Added to section 9-316, however, is subsection (i) that treats after-acquired collateral in the same way that new subsection $(\mathrm{h})$ treats such collateral following the debtor's relocation. ${ }^{74}$ The original filing will continue its job of perfecting the secured party's interest for four months.

One additional point remains. Assume in the previous example that Newcorp had been an established business with inventory prior to the merger with Debtor. When it becomes bound by the security of Debtor, Lender's security interest will attach to the pre-merger inventory and, under subsection (i), that interest will now also be perfected for four months without a filing in Delaware..$^{75}$

73. See supra notes $60-63$ and accompanying text.

74. Compare U.C.C. § 9-316(i) (Approved Amendments 2010) (making financing statements effective to perfect security interests in after-acquired collateral for four months in instances where the statement would have been effective had it been acquired by the original debtor), with id. $\$ 9-316(\mathrm{~h})$ (making financing statements effective to perfect interests for four months in instances where the statement would have been effective had the debtor not changed its location).

75. This new rule necessitated a conforming amendment to section 9-326. See id. §9326(a). Suppose, in our example, that Newcorp had granted a security interest in its inventory to a competing secured party ("SP2") who filed against Newcorp in Delaware. Who would have the priority interest in the inventory? Lender would have priority as to the 


\section{CORRECTION STATEMENTS}

\section{A. The Problem}

Under the current version of UCC section 9-518, the debtor is given a nonjudicial method for providing notice to third parties that a financing statement or other record is inaccurate or wrongfully filed. ${ }^{76}$ Now that financing statements can be filed without the debtor's signature, it certainly makes sense for the statute to give the debtor an opportunity to respond to unauthorized filings. ${ }^{77}$ The debtor can file what is called a "correction statement." In this statement, the debtor will indicate why he believes that there is an error or a wrongful filing and what steps should be taken to eliminate the error. ${ }^{78}$ It is important to understand that although the correction statement is now considered to be part of the financing statement, ${ }^{79}$ it in no way negates its effectiveness. ${ }^{80}$ The Official Comments to section 9-518 point out that this remedy is analogous to the opportunity afforded consumers to correct an erroneous credit report under the Fair Credit Reporting Act. ${ }^{81}$

By way of contrast, suppose that it is not the debtor who has reason to object to a filing, but rather, it is a secured party of record. Such would be the case, for example, if the debtor or a competing creditor were to improperly file a statement that purports to terminate the secured party's financing statement. ${ }^{82} \mathrm{Al}-$ though the termination statement would not impair the effectiveness of the filed financing statement, ${ }^{83}$ the secured party may

inventory obtained from Debtor, but section 9-326 would give SP2 priority as to the afteracquired and pre-merger inventory. See id. $\S 9-326(\mathrm{~b})$.

76. See id. $\$ 9-518(2009)$.

77. Although the financing statement need not be signed to be sufficient, see id. $\S 9$ 502 (a), the filing is not effective unless it is authorized by the debtor in an authenticated record, see id. $\$ 9-509(\mathrm{a})(1)$.

78. Id. $\S 9-518(\mathrm{~b})(3)$.

79. See id. §9-102(a)(39) (The term "financing statement" includes "any filed record relating to the initial financing statement.").

80. See id. \$ 9-518(c).

81. Id. § 9-518 cmt. 2 (citing Fair Credit Reporting Act, Pub. L. No. 91-508, 84 Stat. 1128 (1970) (codified at 15 U.S.C. $\$ 1681$ (2006)). In addition to filing a correction statement under section $9-518$, the debtor may be able to recover actual damages and a $\$ 500$ civil penalty from the person responsible for the inaccurate or wrongful filing. See id. $\$ 9$ 625(b), (e).

82. A "termination statement" does not need the signature of the secured party of record. See id. $\S 9-513$.

83. See id. $\S \S 9-509(\mathrm{~d}), 9-510(\mathrm{a}), 9-519(\mathrm{~g})$. For a recent case that mistakenly held to 
wish to avoid later litigation by giving notice to third parties of its continuing interest. ${ }^{84}$ Unfortunately, a correction statement can only be filed by the debtor. ${ }^{85}$ Unless the secured party can convince the debtor to file such a statement on its behalf, third parties who rely on the public record do so at their peril.

\section{B. The Solution}

Amended Article 9 adds a new subsection (c) to section 9-518, which allows filing of what is now termed an "information statement" by "a secured party of record with respect to the financing statement to which the record relates and [who] believes that the person who filed the record was not entitled to do so under Section 9-509(d)." $" 86$ Thus, no longer would it be necessary for the secured party to urge the cooperation of the debtor to correct the record. Although the information statement would not alter the effectiveness of the termination statement, the risk of there being a secret lien would be eliminated.

\section{RATIFICATION OF AN UNAUTHORIZED FINANCING STATEMENT}

\section{A. The Problem}

As noted earlier, section 9-502(a) deletes the traditional requirement that the debtor's signature must appear on a financing statement. ${ }^{87}$ Under this provision the financing statement need only state the name of the debtor. ${ }^{88}$ Section 9-509(a)(1) allows a person to file an initial financing statement only if "the debtor authorizes the filing in an authenticated record." ${ }^{89}$ If the secured

the contrary, see People's Bank of Ky. v. U.S. Bank, N.A. (In re S.J. Cox Enters.), No. 0750705, 2009 WL 939573, at *4 (Bankr. E.D. Ky. Mar. 4, 2009) ("The termination of a financing statement, even if mistaken, releases the secured creditor's lien against the debtor's property." (citing Crestar Bank v. Neal (In re Kitchin Equip. Co. of Va., Inc.), 960 F.2d 1242, 1245 (4th Cir. 1992))).

84. See U.C.C. $\$ 9-518 \mathrm{cmt}$. 2 (Approved Amendments 2010).

85. See id. $\S 9-518$ (a) \& cmt. 2 (2009) (speaking only in terms of "the debtor").

86. Id. $\$ 9.518$ (c) (Approved Amendments 2010).

87. Id. $\S 9-502(\mathrm{a}) \& \mathrm{cmt} .3$ (2009).

88. Id. $\S 9-502(\mathrm{a})(1)$.

89. Id. $\$ 9-509(\mathrm{a})(1)$ 
party files a financing statement without the requisite authorization by the debtor, the filing is ineffective..$^{90}$

Assume that when the financing statement was first filed by the secured party, the debtor had not yet authorized the filing in an authenticated record. Then, sometime later, the debtor signs a security agreement. Section 9-509(b) provides: "By authenticating ... a security agreement, a debtor ... authorizes the filing of an initial financing statement, and an amendment, covering ... the collateral described in the security agreement . . . ."91

The first issue raised by this fact pattern is whether the signing of the security agreement retroactively authorizes the prior filing, or whether a new filing is required. The Code does not say, but comment 3 to section 9-509 suggests that the concept of ratification would serve to make the prior filing effective. ${ }^{92}$ The second issue is a bit trickier. Suppose that a second secured party files against the same collateral before the earlier filing is ratified. For purposes of the priority rule based upon time of filing ${ }^{99}$ does the ratification make the initial financing statement effective as of the filing date? Or is the financing statement only effective as of the date of the security agreement? It would seem that ratification should make the financing statement effective from the time of filing for all purposes. After all, the second secured party presumably was aware of the earlier filing and should have taken whatever steps it thought necessary to protect its interests. But until Amended Article 9 takes effect, the result is uncertain.

\section{B. The Solution}

The response of the Drafting Committee to this problem and the last remaining problem to be discussed in this article was not to tinker with the statutory text, but rather, to add clarifying language to the official comments. The language is as follows:

90. See id. $\$ 9-510$ (a) ("A filed record is effective only to the extent that it was filed by a person that may file it under Section 9-509."). Moreover, the debtor is entitled to compensatory damages under section 9-625(b) and statutory damages under section 9-625 (e)(3). See id. \$ 9-625(b), (e)(3).

91. Id. $\S 9-509(\mathrm{~b})(1)$.

92. See id. $\$ 9-509 \mathrm{cmt}$. 3 ("Law other than this Article, including the law with respect to ratification of past acts, generally determines whether a person has the requisite authority to file a record under this section.").

93. See id. § 9-322(a)(1) ("Conflicting perfected security interests . . rank according to priority in time of filing or perfection."). 
Under a notice-filing system, a filed financing statement indicates to third parties that a person may have a security interest in the collateral indicated. With further inquiry, they may discover the complete state of affairs. When a financing statement that is ineffective when filed becomes effective thereafter, the policy underlying the noticefiling system determines the "time of filing" for purposes of [section 9.322(a)(1)]. For example, the unauthorized filing of an otherwise sufficient initial financing statement becomes authorized, and the financing statement becomes effective, upon the debtor's post-filing authorization or ratification of the filing. Because the authorization or ratification does not increase the notice value of the financing statement, the time of the unauthorized filing is the "time of filing" for purposes of subsection (a)(1). The same policy applies to the other priority rules in this part. ${ }^{94}$

A brief comment on the Review Committee's decision to address specific problems in the comments is in order. The most obvious point is that, although comments play an extremely prominent role in Code interpretation, they are not part of the statutory text, nor are they legislative history of the enacting state legislatures in the usual sense..$^{95}$ The point is significant in those instances where the comment goes beyond or does not fit the statutory text. Here courts ought to be extremely cautious in attributing persuasive weight to the comment. By following a comment on a matter that does not appear in the text, courts risk carrying out policies that cannot be tied to any legislative judgment. The problem has arisen in many cases where the comments seem designed to function more as legislation than merely as a means of discerning the meaning of statutory language. ${ }^{96}$

94. Id. § 9-322 cmt. 4 (Approved Amendments 2010) (internal citation omitted).

95. To be sure, "[t]he courts take to the comments like ducks to water, even though the legislatures did not enact the comments." JAMES J. WhITE \& ROBERT S. SUMMERS, UNIFORM COMMERCIAL CODE: SECURED TRANSACTIONS $\S 5$, at 13 (5th ed. 2000); see also Laurens Walker, Writings on the Margin of American Law: Committee Notes, Comments, and Commentary, 29 GA. L. REv. 993, 1013 (1995) ("Courts have cited the comments thousands of times, often affording them great weight."); Sean Michael Hannaway, Note, The Jurisprudence and Judicial Treatment of the Comments to the Uniform Commercial Code, 75 CORNELL L. REV. 962, 975 (1990) ("In the great majority of cases, courts cite the [c]omments to support the application or purpose described in them.").

96. See, e.g., WhITE \& SUMMERS, supra note 95, at 13-14 ("[T] from the text in two different ways. They sometimes expand on, and therefore go beyond the text, and they sometimes restrict or narrow the meaning of the text."); Hannaway, supra note 95, at 975-85 (discussing several instances where the "[c]omments [are] [a]cting as Code"). The point is explicitly recognized by the New York Law Revision Commission in its criticism of the comments:

A more serious objection arises from instances in which the [c]omments appear to qualify the text or to add further rules not supported by the text. (See, 
An example of the central idea here is former comment 3 to section 2-507.97 Section 2-507(2) gives a seller the right to reclaim goods from a cash buyer who has paid with a "rubber check." But unlike section 2-702(2), which permits a seller to recover goods from a credit buyer who has received the goods while insolvent, section 2-507(2) is silent on the question of when demand for reclamation must occur. ${ }^{99}$ Before it was amended in 1990, comment 3 to section 2-507 contained an unexplained assertion: "The provision of this Article for a ten day limit within which the seller may reclaim goods delivered on credit to an insolvent buyer is also applicable here." ${ }^{100}$ Relying on this comment, several courts have unhesitatingly imposed a ten-day limit on reclamation applicable to cash sales. ${ }^{101}$

e.g., Comments 1, 6, and 9 to Section 1-205, Comment 2 to Section 2-205, Comments 4, 8, and 13 to Section 2-320, Comments 1 and 2 to Section 2-508, Comment 4 to Section 2-509, Comment 5 to Section 2-607, Comment 2 to Section 3-510, Comment 2 to Section 4-212, Comment 9 to Section 4-403, Comments 1 and 4 to Section 7-501, Comment to Section 8-303, Comment 3 to Section 8-313, Comment 8 to Section 9-204, Comment 5 to Section 9-318.)

N.Y. STATE LAW REvision COMm'N, REPoRT of THE N.Y. STATE LAW REvision COMM'N for 1956, at 26 (1956).

97. See U.C.C. $\$ 2-507$ cmt. 3 (1978).

98. See id. $\S 2-507(2)(2009)$. Even though payment is by check, the transaction is considered to be a cash sale. No credit is extended. See Stowers v. Mahon (In re Samuels \& Co.), 526 F.2d 1238, 1241 (5th Cir. 1976). In such cases, section 2-507(2) provides that "[w]here payment is due and demanded on the delivery to the buyer of goods or documents of title, his right as against the seller to retain or dispose of them is conditional upon his making the payment due." U.C.C. $§ 2-507(2)$. Under section 2-511(3), "payment by check is conditional and is defeated as between the parties by dishonor of the check on due presentment." Id. \$2-511(3).

99. Section 2-702(2) provides in pertinent part:

Where the seller discovers that the buyer has received goods on credit while insolvent he may reclaim the goods upon demand made within ten days after the receipt, but if misrepresentation of solvency has been made to the particular seller in writing within three months before delivery the ten day limitation does not apply.

Id. $\S 2-702(2)$.

100. Id. $\$ 2-507 \mathrm{cmt} .3$ (1978). In 1990, The Permanent Editorial Board ("PEB") for the Uniform Commercial Code amended comment 3 by deleting the reference to a ten-day li. mitation and substituting in its place an explicit statement that "[ $t$ ]here is no specific time limit for a cash seller to exercise the right of reclamation." PEB Commentary on the Uniform Commercial Code: Commentary No. 1 (1990).

101. See, e.g., Szabo v. Vinton Motors, Inc., 630 F.2d 1, 4 (1st Cir. 1980) ("We hold that the ten day limitation period contained in [c]omment 3 provides a more certain guide for conducting commercial transactions than the common law yardstick of "reasonableness," and that it will encourage cash sellers to make prompt presentment. Any extension of the ten day limitation period based on the realities of the commercial banking world is for the legislature, not this Court."). Analytically, the court's opinion is unsatisfying. As Professor Walker notes: "[T] he First Circuit announced the curious view that the comment merited 
It is clear that there are potential benefits to be gained from the comments. The task for any drafting committee and its reporter is to take an appropriate approach to the comments to ensure that such gains are realized. It is one thing to justify the use of comments generally. It is quite another, however, to determine the particular fit between text and comments on a particular issue. Insofar as the question of allocation is concerned, the decision to address its effects in a comment, rather than the text, is probably of little significance since the courts would seemingly reach the suggested approach, even without specific guidance. On the other hand, the same cannot be said for the problem discussed in the next Part of this article.

\section{The COMMERCIAL MONEY CENTER CASE}

\section{A. The Problem}

In re Commercial Money Center, Inc. illustrates the problem of "stripping" for which there is currently no "right" statutory solution. ${ }^{102}$ In this case, Commercial Money Center, Inc. ("CMCI") was in the business of leasing equipment. ${ }^{103}$ It would package groups of leases together and assign only its right to receive future rentals to various entities, thus "stripping" the anticipated payment streams from the remainder of the leases. ${ }^{104}$

In CMCI's bankruptcy, the trustee sought to avoid the transfer of the payment streams using the "strong arm" clause codified in Bankruptcy Code $\S 544(a)(1) .{ }^{105}$ The assignee argued that under the personal property categorization scheme of Article 9, the un-

weight and should only be changed by legislation, even though the comment itself had never been enacted." Walker, supra note 95, at 1015. Now that the PEB (a nonlegislative body) has acted to change the comment one wonders whether the First Circuit would, if presented with the same issue today, reach a different conclusion.

102. Kipperman v. Netbank, FSB (In re Commercial Money Ctr., Inc.), No. 02-09721, 2005 WL 1365055 (Bankr. S.D. Cal. Jan. 27, 2005), aff'd in part, 350 B.R. 465, (B.A.P. 9th Cir. 2006). Compare, for example, the opposing declarations of expert witnesses and coreporters for Revised Article 9, Charles W. Mooney, Jr. and Steven L. Harris, which the bankruptcy court excluded. See In re Commercial Money Ctr., 350 B.R. at 480 n.12.

103. In re Commercial Money Ctr., 2005 WL 1365055 , at * 1 .

104. Id.

105. In re Commercial Money Ctr., 350 B.R. at 472. The strong arm clause gives the bankruptcy trustee the rights and powers of a hypothetical judicial lien creditor. 11 U.S.C. $\$ 544(a)(1)$ (2006). Since, under governing law, an unperfected security interest would be subordinate to a judicial lien, U.C.C. $\$ 9-317(a)(2)(A)(2009)$, section 544(a)(1) empowers the trustee to avoid the unperfected security interest. 
derlying transactions involved the sale of payment intangibles. ${ }^{106}$ As such, the assignee's interest in the payment streams was automatically perfected upon attachment under Code section 9 . 309(3). ${ }^{107}$ The trustee, however, argued the transaction was not a sale of payment intangibles, but was instead either a loan or a transfer of an interest in chattel paper. ${ }^{108}$ In that case, the assignee's interest in the payment streams could be perfected only by filing under section 9-312(a) or by taking possession of the lease agreements under section 9-313(a). ${ }^{109}$ Thus, a key issue in the case became the threshold matter of identifying the proper characterization of the transaction under the elaborate provisions of the UCC. ${ }^{110}$

The bankruptcy court held for the trustee. ${ }^{111}$ On appeal, the Bankruptcy Appellate Panel for the Ninth Circuit ("B.A.P.") disagreed with the lower court as to the nature of the collateral. ${ }^{112}$ The panel opined that the payment streams, having been stripped from the underlying chattel paper, reduced the transaction to the transfer of an interest in payment intangibles, for which automatic perfection was unavailable because the transaction was a loan. ${ }^{113}$

This latter conclusion is problematic. At the very least, payment stripping may have a detrimental effect on the ability to know one's priority in purchased or pledged chattel paper, as illustrated by the following example. Suppose that on March 1, Debtor leases equipment to X; on April 1, Secured Party 1 ("SP1") acquires a security interest, perfected by filing, in the lease; and on June 1, Secured Party 2 ("SP2") purchases the lease for new value

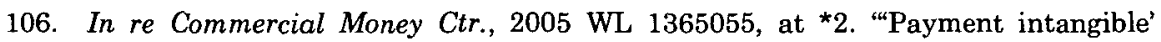
means a general intangible under which the account debtor's principal obligation is a monetary obligation." U.C.C. § 9-102(61).

107. In re Commercial Money Ctr., 2005 WL 1365055, at *1.

108. Id. Chattel paper includes "a record or records that evidence both a monetary obli. gation and ... . a lease of specific goods. ... [Under this definition], 'monetary obligation' means a monetary obligation . . owed under a lease of [specific] goods . . ." U.C.C. § 9 102(11).

109. In re Commercial Money Ctr., 2005 WL 1365055, at *2.

110. Id.

111. Id. at *4. Alternatively, the bankruptcy court ruled that even if the payment streams were severable from the underlying leases, the automatic perfection rule of section 9-309(3) would nevertheless not apply because the true nature of the transactions were loans, not sales. Id. at *7, *11.

112. In re Commercial Money Ctr., 350 B.R. at 469.

113. Id. 
and takes possession of the paper. ${ }^{114}$ Under section 9-330(a) or (b), the purchaser can achieve priority over the earlier-in-time security interest. ${ }^{115}$ Even if priority were not obtainable, SP2 should not have been misled because it could have easily learned of the earlier security interest by checking for UCC filings. Now, changing the facts, assume instead that the payment stream is permissibly stripped from the underlying lease and sold to SP1 in its new form as a payment intangible. As noted, SP1's interest would be automatically perfected and no filing would be necessary. ${ }^{116}$ This creates some complexities for determining priority as to the payment stream. If section 9.330 is applied, SP2 would presumably have priority. But the application of section 9-330 in this context is open to question. Both subsections (a) and (b) accord the laterin-time chattel paper purchaser "priority over a security interest in the chattel paper." 117 No hint is given whether this same laterin-time priority would apply if the earlier interest was a payment intangible. ${ }^{118}$ If not, any subsequent buyer of, or party secured by, Debtor's chattel paper would always run the risk-realized here-that it would have no meaningful interest in the chattel paper. ${ }^{119}$ This risk should negatively impact the value that third parties place on Debtor's chattel paper. ${ }^{120}$

114. Keep in mind that the term "purchaser" is broadly defined in the Code to include one whose interest secures an obligation. See U.C.C. $\$ 1-201(30)$ (2009).

115. Under section $9-330(a)$, the purchaser can achieve priority over a competing security interest "which is claimed merely as proceeds of inventory subject to a security interest if . . . the chattel paper does not indicate that it has been assigned to an identified as. signee other than the purchaser." Id. $\S 9-330(\mathrm{a})(2)$. Subsection (b) applies if the security interest is not claimed "merely as proceeds." Id. $\S 9-330(\mathrm{~b})$. In that case, the purchaser can achieve priority if it buys or takes its security interest "without knowledge that the purchase violates the rights of the secured party." Id.

116. See supra notes 106-07 and accompanying text.

117. U.C.C. $\$ 9-330(a),(b)$.

118. The B.A.P. in In re Commercial Money Center, Inc. was not unaware of this issue but chose to leave its resolution for another day. See In re Commercial Money Ctr., 350 B.R. at 480 ("We explicitly decline to resolve this ambiguity in Revised U.C.C. Section 9330(b) ....").

119. Note that one in the position of SP2 will almost surely ask Debtor to represent and warrant that the payment stream had not been previously stripped from the chattel paper, but if Debtor breaches this promise, SP2 will hold only an unsecured claim for damages.

120. This problem of uncertain priorities and the consequent devaluation of property has to be faced whenever automatic perfection is permitted. Thus, section 9-309(3) should give pause to any party contemplating a transaction involving payment intangibles. For all she knows, they have already been sold. 


\section{B. The Solution}

Amended Article 9 attempts to solve the foregoing problem by amending the Official Comment rather than the statute. In a onesentence addition to section $9-102$ comment $5(\mathrm{~d})$, the point is made that even if the rental stream is separated, the rental stream is still "chattel paper."121 Given the current textual ambiguity on this point and the fact that application of the approach espoused by the new comment may yield results that some find objectionable, it is not surprising that the Drafting Committee would hesitate to confront the detractors head-on by amending several provisions of the statute. Still, despite its simplicity and relative ease of application, there are several reasons to be less than sanguine that the comment will succeed in putting the issue to rest.

First, nothing compels a court to embrace the comment if it does not believe that the comment states a correct interpretation of the Code, as currently drafted. ${ }^{122}$ Moreover, are we to necessarily assume that a single sentence in the comment will have more persuasive force than the B.A.P.'s analysis in Commercial Money Center?

Second, the new comment is in a paragraph that begins with a statement that "[a] right to the payment of money is frequently buttressed by ancillary rights" and goes on to say that Article 9 "does not treat these ancillary rights separately from the rights to payment to which they relate." ${ }^{23}$ What if the lessee has payment obligations in addition to the obligation to pay rent (e.g., an obligation to pay for insurance)? Would these obligations be considered ancillary and therefore within the scope of the interest transferred to the secured party?

121. The sentence reads as follows: "Contrary to the opinion in In re Commercial Money Center, Inc., . . . if the lessor's rights under a lease constitute chattel paper, an assignment of the lessor's right to payment under the lease also would be an assignment of chattel paper, even if the assignment excludes other rights." U.C.C. $\$ 9-102 \mathrm{cmt}$. 5(d) (Approved Amendments 2010).

122. See Pride Hyundai, Inc. v. Chrysler Fin. Co., 369 F.3d 603, 614 (1st Cir. 2004) (discussing how the "majority viewpoint, routinely treat[s] Official Comments to the Code that have not been enacted as highly persuasive authority"); Nigel Stark, Note, Unofficial Official Comments, 11 TEX. REV. L. \& POL. 479, 488 (2007) ("[T]he Official Comments of the UCC . . . lack the constitutionally prescribed authority to be binding law.").

123. U.C.C. $\S 9-102 \mathrm{cmt}$. $5 \mathrm{~d}$. 
Third, the new comment is arguably inconsistent with the immediately preceding paragraph. That paragraph reads:

In classifying intangible collateral, a court should begin by identifying the particular rights that have been assigned. The account debtor (promisor) under a particular contract may owe several types of monetary obligations as well as other, nonmonetary obligations. If the promisee's right to payment of money is assigned separately, the right is an account or payment intangible, depending on how the account debtor's obligation arose. ${ }^{124}$

All of this leads up to a concluding remark about legislation by comment. It is crucial to distinguish between those situations where an amended comment directly conflicts with existing case law and those where it does not. ${ }^{125}$ Although in both instances the comments can be used positively by providing a set of expert judgments about what the law should be, it is in the former instance that the comment may fail to create a particularly favorable environment for the development of a uniform commercial law. This may be especially true when the comment fails to explain why the conflicting judicial analysis is flawed. In other words, the comment should offer some reason for believing that the case law is wrong, rather than simply disparaging its evolution. It may be, therefore, that until the Code is actually amended to address the problem of stripping, the real solution will remain elusive.

\section{CONCLUSION}

If the history of the Code and its many revisions and amendments teach anything, it is that the solutions to the problems of commercial law do not always come easily. This, in itself, is a lesson worth remembering, because too often, simple solutions are offered without appreciation of the true dimensions of the problem and its real causes. It was none other than the Chief Reporter and overall architect of the original Code, Karl Llewellyn, who said that "until the rules of law themselves are effectively and realistically adjusted to what commerce needs immediately, and to what All-of-Us need indirectly, we are doomed to an unfortu-

124. Id.

125. The Drafting Committee also amended comment 9 to section 8.103 to reject the holding of Highland Capital Management LP v. Schneider, 866 N.E.2d 1020, 1024 (N.Y. 2007). U.C.C. $\$ 8-102 \mathrm{cmt} .13$. 
nate measure of waste in legal work, of unsatisfactory uncertainty and too frequent nonsense in result." ${ }^{126}$ The challenge for any drafting committee is to capture the good and avoid the nonsense. All in all, the Article 9 Committee has succeeded.

126. K. N. Llewellyn, The Modern Approach to Counseling and Advocacy-Especially in Commercial Transactions, 46 CoLUM. L. REV. 167, 178 (1946). 
